\title{
Early Precambrian mantle derived rocks in the southern Prince Charles Mountains, East Antarctica: age and isotopic constraints
}

\author{
E. V. Mikhalsky, ${ }^{1}$ F. Henjes-Kunst, ${ }^{2}$ and N. W. Roland ${ }^{2}$ \\ ${ }^{1}$ VNIIOkeangeologia, Angliisky ave., 1, St.-Petersburg 190121, Russia \\ ${ }^{2}$ Bundesanstalt für Geowissenschaften und Rohstoffe, Stilleweg, 2, Hannover 30655, Germany
}

\begin{abstract}
Mafic and ultramafic rocks occurring as lenses, boudins, and tectonic slabs within metamorphic units in the southern Mawson Escarpment display mantle characteristics of either a highly enriched, or highly depleted nature. Fractionation of these mantle rocks from their sources may be as old as Eoarchaean (ca $3850 \mathrm{Ma}$ ) while their tectonic emplacement probably occurred prior to $2550 \mathrm{Ma}$ (U-Pb SHRIMP data). These results provide for the first time evidence for Archaean suturing within East Antarctica. Similar upper mantle sources are likely present in the northern Mawson Escarpment. A younger age limit of these rocks is $2200 \mathrm{Ma}$, as indicated by presumably metamorphic zircon ages while their magmatic age may be constrained by single zircon dates at 2450-2250 Ma. The area of the northern Mawson Escarpment is most likely of ensimatic origin and includes mafic rocks which were derived from distinct mantle source(s) during Palaeoproterozoic time.
\end{abstract}

Citation: Mikhalsky, E.V., F. Henjes-Kunst, and N.W. Roland (2007), Early Precambrian mantle derived rocks in the southern Prince Charles Mountains, East Antarctica: age and isotopic constraints, in Antarctica: A Keystone in a Changing World - online Proceedings of the 10 $0^{\text {th }}$ ISAES, edited by A.K. Cooper and C.R. Raymond et al., USGS Open-File Report 2007-1047, Short Research Paper 039, 4 p.; doi:10.3133/of2007-1047.srp039

\section{Introduction}

East Antarctica is well known for its high-grade metamorphic rocks - felsic (granitic to trondhjemitic) orthogneisses or paragneisses. These rocks are up to

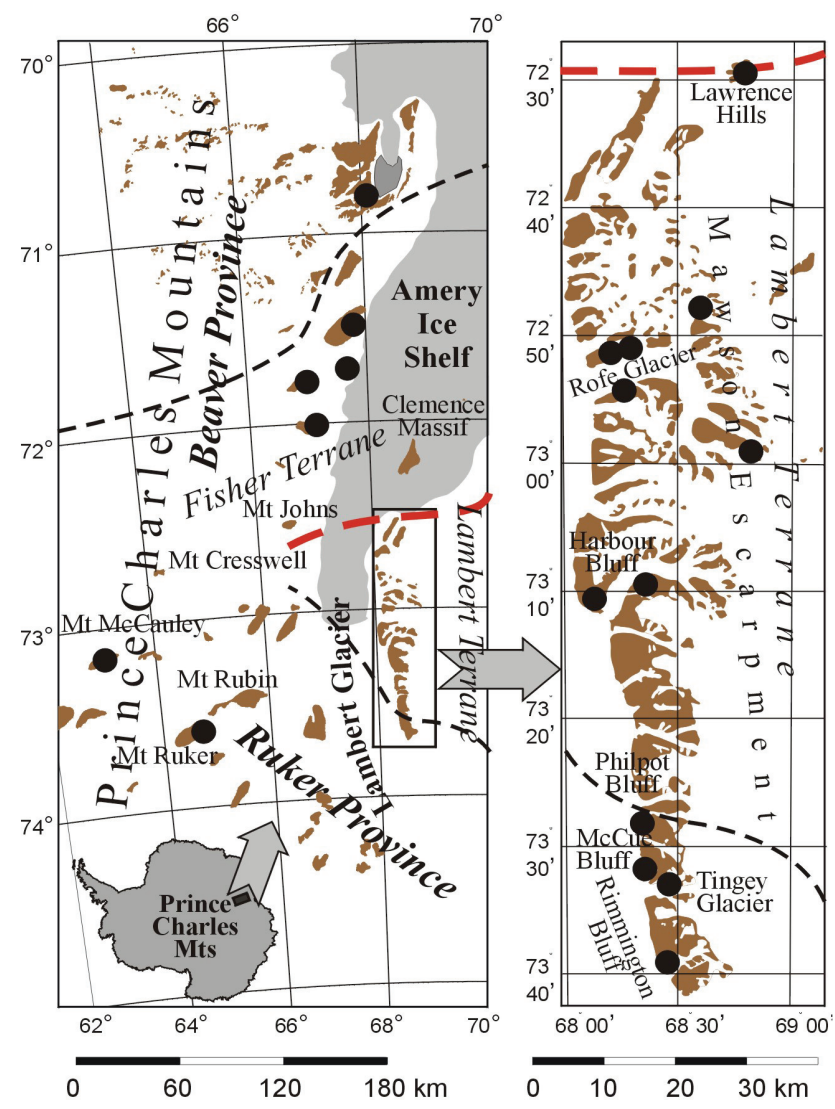

Figure 1. Locality map, showing occurrences of ultramafic rocks in the Prince Charles Mountains (thick dot). Thick red dashed line - province boundary, black dashed line - terrane boundary.
3800-3900 Ma old as evidenced by zircon U-Pb studies (Harley \& Black, 1997) and corresponding Sm-Nd model ages (Grikurov \& Mikhalsky, 2002 and references therein). The latter indicate that parts of the East Antarctic crust were derived from the mantle as early as in the Eoarchaean. However, there are only rare occurrences of mantle-derived rocks retaining their primary mantle characteristics, which were not reworked during subsequent events. The southern Prince Charles Mountains (sPCM) is one of a few areas in East Antarctica where Archaean metamorphic rocks occur. Furthermore, locally abundant mafic to ultramafic rocks of presumably mantle origin occur in this area. The SPCM are underlain by Mesoarchaean to Neoproterozoic Ruker Province (Phillips et al., 2006), a part of which (central and northern Mawson Escarpment) may be distinguished as Palaeoproterozoic Lambert Terrane (Kamenev et al., 1993, Mikhalsky et al., 2006, Boger et al., 2006). The central and northern parts of the Prince Charles Mountains are underlain by Meso- to Neoproterozoic Beaver (or Rayner, by some authors) Province, with the Fisher Terrane forming a southern part of it (Fig. 1). In this report we present new geological and isotopic $(\mathrm{U}-\mathrm{Pb}$ SHRIMP and Sm-Nd) data for mafic to ultramafic rocks from the Mawson Escarpment in the sPCM and put some geochemical and age constraints on their mantle sources.

\section{Southern Mawson Escarpment}

Mantle derived mafic and ultramafic rocks occur as small lenses, boudins or larger blocks and tectonic slabs within metamorphic units. Typically, these rocks occur as chains and groups of boudins enclosed in steeply dipping, generally east-west trending high-strain shear zones or as scattered boudins within felsic granite-gneiss. These rocks consist of amphibole (actinolite, tremolite, or anthophyllite), magnetite, relict orthopyroxene and olivine, and secondary talc, serpentine, epidote, phlogopite, carbonate, chlorite, and titanite. Less altered 
rocks are olivine orthopyroxenite, amphibole orthopyroxenite, dunite, and amphibole dunite. The rocks apparently experienced two metamorphic events.

The most prominent high-strain shear zone runs along the northern fringe of Tingey Glacier. Here ultramafic and less abundant mafic lenses and blocks occur within a 50-

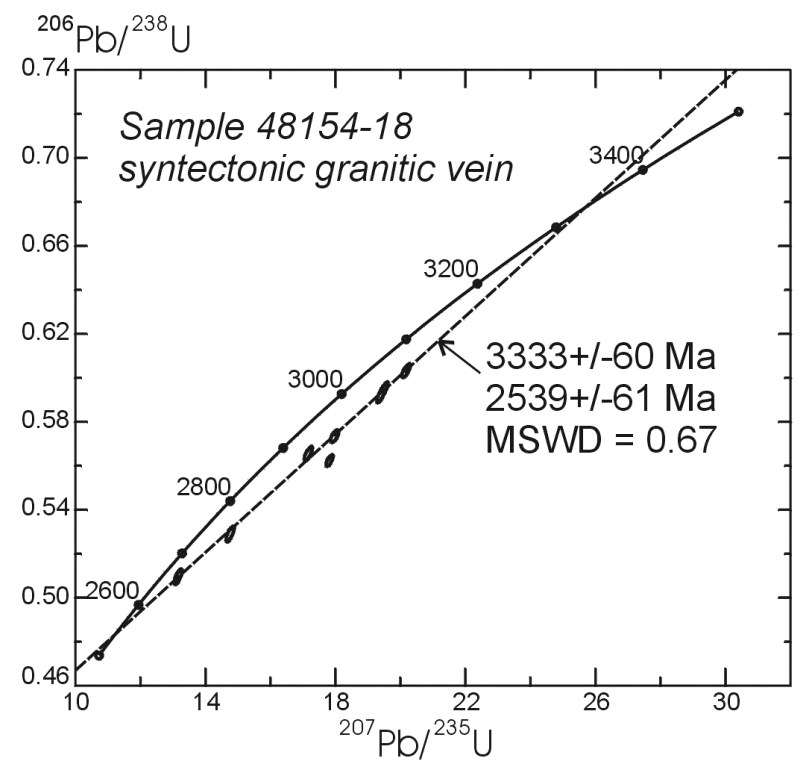

Figure 2. U-Pb concordia plot for a granitic vein from the Tingey Glacier area.
$100 \mathrm{~m}$ thick tectonic melange zone. A syntectonic felsic vein from this melange zone was studied for zircon chronology by SHRIMP at the Isotopic Center (VSEGEI, St. Petersburg). Zircon grains are of elongated prismatic (apparently magmatic) shape and are inhomogeneous in terms of the inner structure (core and thick mantle). Seven mantle analyses on seven grains were obtained $(\mathrm{Th} / \mathrm{U}=$ $0.12-0.18$ ), all are highly discordant, but six of these form a reference line with an upper intercept at $3333 \pm 60 \mathrm{Ma}$, and a lower intercept at $2539 \pm 61 \mathrm{Ma}$ (Fig. 2). The upper intercept is close to the emplacement age of trondhjemitic gneiss (3377 \pm 9 Ma, Mikhalsky et al., 2006) to the north of Tingey Glacier, but older than the emplacement age of granitic gneiss (3180-3170 Ma, Mikhalsky et al., 2006, Boger et al., 2006) south Tingey Glacier. The lower intercept is close to the age of a post-tectonic pegmatite vein (ca $2650 \mathrm{Ma}$, Boger et al., 2006), but may be influenced by thermal overprint, distinguished by Boger et al. (2006). We interpret the ca $3330 \mathrm{Ma}$ age as inherited, and the ca $2550 \mathrm{Ma}$ date as the younger age limit of tectonic melange.

Sm-Nd data were obtained at the BGR (Hannover). Ultramafic and mafic rocks have highly variable $\mathrm{Sm} / \mathrm{Nd}$ ratios $\left(\mathrm{f}_{\mathrm{Sm} / \mathrm{Nd}}=-0.30--0.10\right.$, up to 0.30 , where $\mathrm{f}_{\mathrm{Sm}-\mathrm{Nd}}=$ $\left({ }^{147} \mathrm{Sm} /{ }^{144} \mathrm{Nd}_{\mathrm{sam}} /{ }^{147} \mathrm{Sm} /{ }^{144} \mathrm{Nd}_{\mathrm{CHUR}}\right)$ - 1) with single stage $\mathrm{T}_{\mathrm{DM}}$ model ages between 2.0-4.2 Ga, but strikingly consistent $\varepsilon_{\mathrm{Nd}}(0)$ values of mostly between $-19--23$ (Fig. 3 a). A two point $(\mathrm{Cpx}-\mathrm{WR})$ reference line
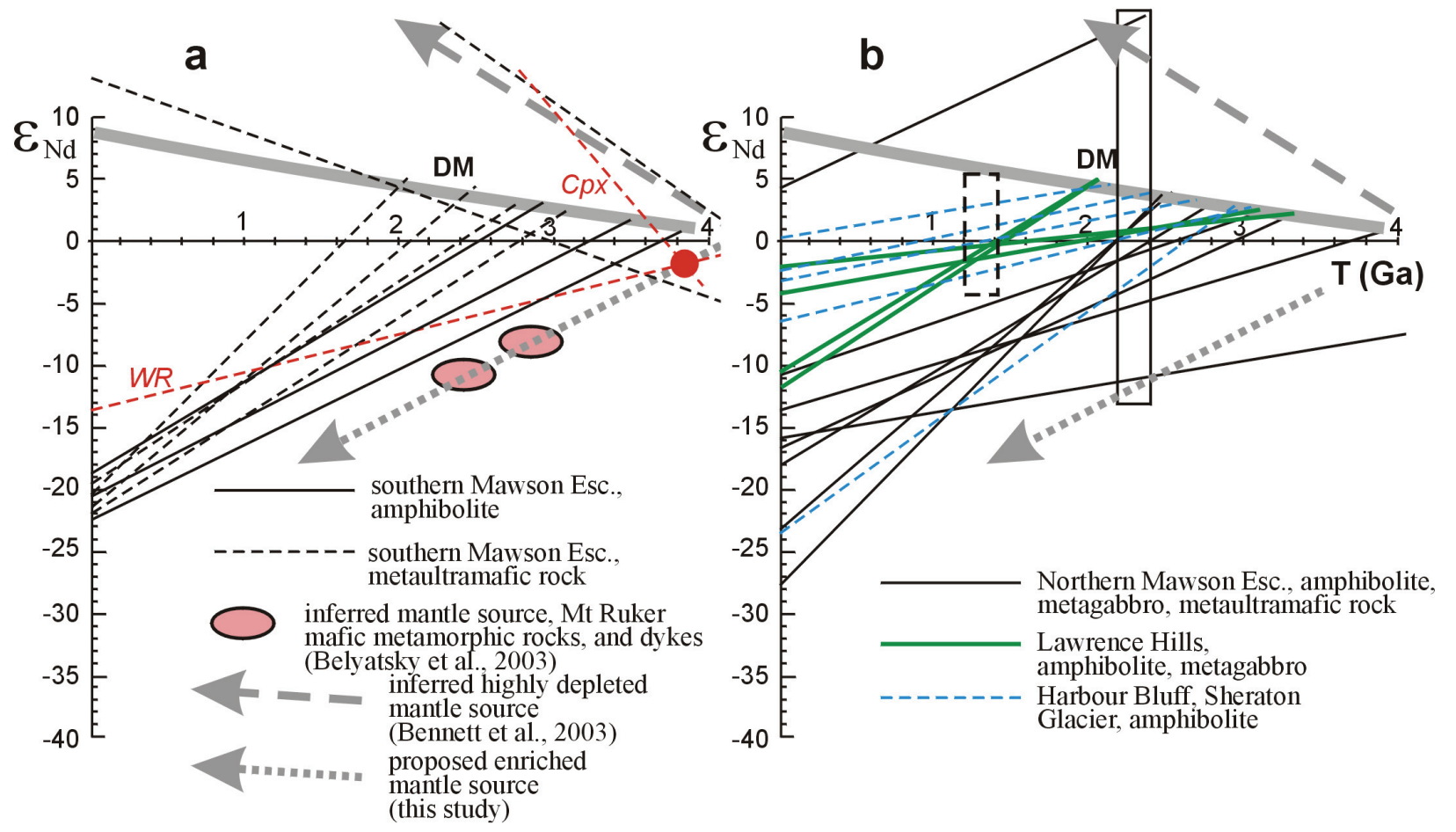

Figure 3. Sm-Nd evolution diagram for ultramafic and mafic rocks from the southern (a) and northern (b) Mawson Escarpment. See text for explanations. 

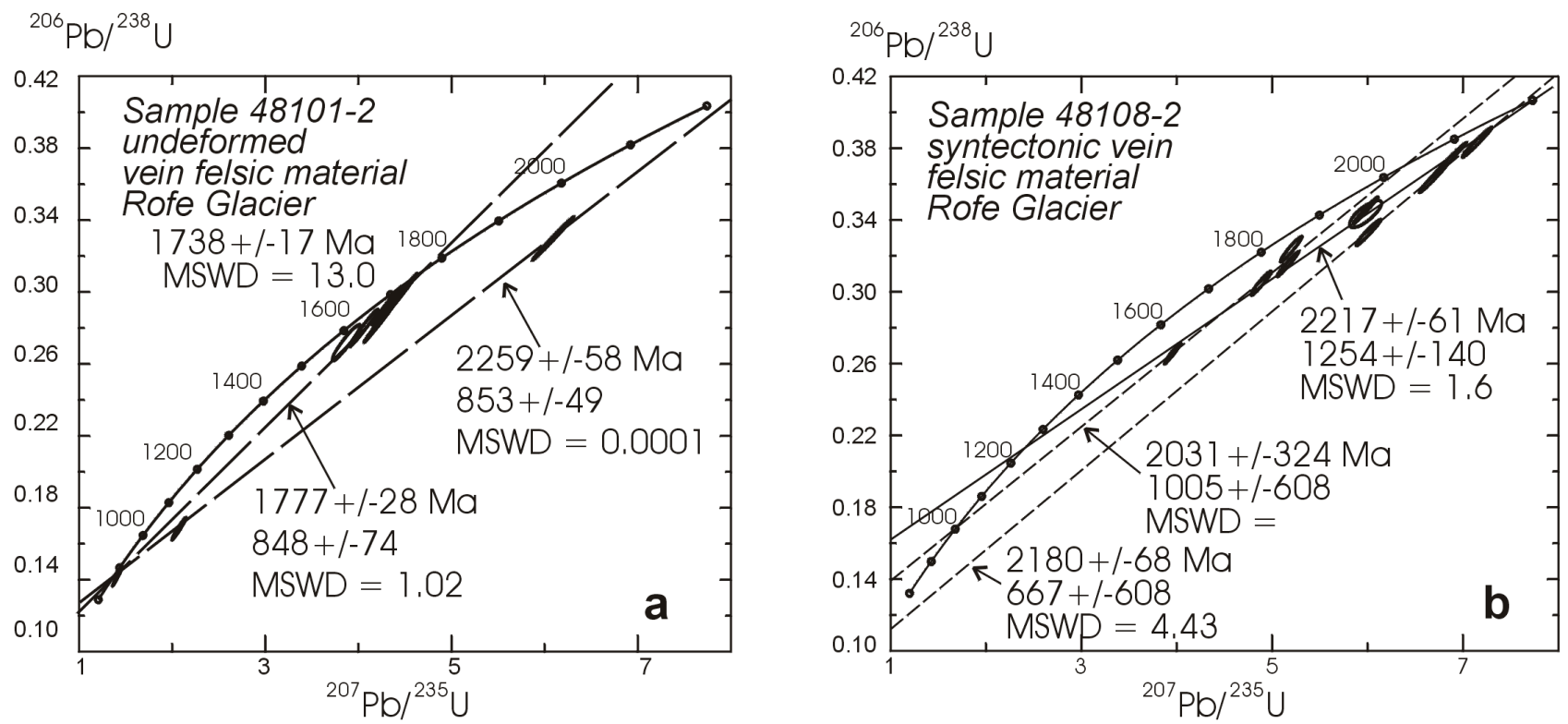

Figure 4. $\mathrm{U}-\mathrm{Pb}$ concordia plots for granitic veins from the northern Mawson Escarpment.

defines an age of ca 3850 Ma with $\varepsilon_{\mathrm{Nd}}(\mathrm{t})=-2$ for a least altered rock. We refer these values to the approximate age when the rock was formed in the upper mantle and to the primary composition of the upper mantle source, respectively. The other rocks likely experienced $\mathrm{Sm}-\mathrm{Nd}$ fractionation during the subsequent metamorphic events which caused the apparent $\mathrm{T}_{\mathrm{DM}}$ scatter. Highly enriched mantle sources have been previously reported from Mt Ruker (Belyatsky et al., 2003; Fig. 3 a). These sources, and the newly defined composition in southern Mawson Escarpment define an evolution trend in Fig. 3 providing evidence that a highly enriched mantle source underlay the southern Ruker province during the Archaean. However, one sample has a very high $\mathrm{f}_{\mathrm{Sm} / \mathrm{Nd}}$ and a $\mathrm{T}_{\mathrm{CHUR}}$ model age of ca $4.2 \mathrm{Ga}$ which closely matches the composition of the presumed early Archaean highly depleted mantle reported by Bennett et al. (1993). Accordingly, isotope data of mafic to ultramafic rocks from the sPCM point to a heterogeneous character of the mantle.

\section{Northern Mawson Escarpment}

In the Rofe Glacier area a predominantly mafic-ultramafic unit, cropping out as isolated blocks or lenses and spatially associated with marble and paragneiss, shows compositional layering suggestive of a plutonic origin. A wide variety range of ultramafic rocks was found: orthopyroxenite, websterite, peridotite, dunite, hornblendite; some varieties are of strongly ferruginous composition. Mafic rocks include hornblendeclinopyroxene-plagioclase, hornblende-plagioclase schist, metagabbro and garnet amphibolite. Ultramafic rocks seem to have undergone only minor metamorphic transformation. Pale-green amphibole or cummingtonite and phlogopite are all in textural equilibrium with olivine and pyroxenes. This suggests that these minerals crystallized early in the rock evolution, maybe at upper mantle conditions. The geochemical features point to an origin of the unit by igneous fractionation and/or accumulation processes.

A late tectonic undeformed leucocratic quartz-feldspar leucosome within one of the ultramafic/mafic bodies contains rounded zircon grains with low $\mathrm{Th} / \mathrm{U}=0.03$ 0.05 except one prismatic grain (0.80). All analyses are to some degree discordant, and eight low- $\mathrm{Th} / \mathrm{U}$ analyses give an upper intercept at ca. $1740 \mathrm{Ma}$ (Fig. 4 a), which is believed to reflect the synmetamorphic leucosome emplacement age. A high- $\mathrm{Th} / \mathrm{U}$ analysis suggests the presence of inherited material of ca $2250 \mathrm{Ma}$ age, which may reflect the emplacement age of mafic protolith. A sample from a syntectonic vein contains rounded inhomogeneous zircon grains, which have domains of high (0.13-0.67) and low (0.04) Th/U ratios. Ten analyses were obtained, with low- $\mathrm{Th} / \mathrm{U}$ analyses displaying more pronounced $\mathrm{Pb}$ loss. Eight analyses form a reference line (Fig. 4 b) with an upper intercept at $2217 \pm 61 \mathrm{Ma}$, and a lower intercept at ca $1250 \mathrm{Ma}(\mathrm{MSWD}=1.6)$, which we interpret as crystallisation age, and thermal overprint age, respectively. U-Pb zircon ages of 2150-2000 Ma and a concordant zircon analysis at ca $2450 \mathrm{Ma}$ were also obtained for a host amphibolite by A. Corvino (personal communication).

Mafic and ultramafic rocks in the northern Mawson Escarpment have highly variable $\mathrm{Sm}-\mathrm{Nd}$ isotopic characteristics: $\mathrm{f}_{\mathrm{Sm}-\mathrm{Nd}}=-0.08--0.50, \mathrm{~T}_{\mathrm{DM}}=0.6-3.8 \mathrm{Ma}$, $\varepsilon_{\mathrm{Nd}}(0)=-28-+4$ (Fig. 3 b). This scatter may be explained by mixing of two end-members (stretched vertical rectangle in Fig. 3 b), which may be the highly 
depleted, and highly enriched reservoirs already identified in the southern Mawson Escarpment.

\section{Central Mawson Escarpment and other areas}

In the central part of the Mawson Escarpment (Philpot Bluff - Harbour Bluff) amphibolite crops out as thin layers (meta-dykes?) or thicker members (metagabbro?) intercalated with felsic quartz-feldspar gneiss. These rocks have $\mathrm{Sm}-\mathrm{Nd}$ isotopic compositions that are strikingly different from the aforementioned mafic rocks in the northern and southern Mawson Escarpment: $\varepsilon_{\mathrm{Nd}}(0)$ $=-6-0, \mathrm{f}_{\mathrm{Sm}-\mathrm{Nd}}=-0.08--0.12$. These features are typical of rocks from the Fisher Terrane bordering the Ruker Province from the north (Mikhalsky et al., 2001 and references therein, dashed rectangle in Fig. 3 b). Similar amphibolites also crop out at Lawrence Hills, Mt Cresswell, Mt Johns, and Shaw Massif.

\section{Conclusions}

1. In the southern Mawson Escarpment ultramafic and mafic rocks display mantle characteristics of complementary highly enriched, and highly depleted nature. The age of these rocks may be as old as Eoarchaean (ca $3850 \mathrm{Ma}$ ), which corresponds to the earlier observed ages of crustal protoliths in Enderby Land. The time of tectonic emplacement of these rocks in the middle crustal level may not be established from our data, but is definitely older than $2550 \mathrm{Ma}$. This fact for the first time provides evidence for Archaean suturing within the present East Antarctica.

2. In the northern Mawson Escarpment ultramafic and mafic rocks represent a Palaeoproterozoic dismembered igneous complex of mantle origin. These rocks were derived by mixing of two contrasting mantle sources: highly enriched and highly depleted reservoirs. The younger age limit of these rocks is ca $2200 \mathrm{Ma}$, as indicated by presumably metamorphic zircon ages (orogeny at ca 2.2-2.0 Ga?), and the older age limit may be indicated by single zircon dates at ca 2450-2250 Ma.

3. The Archaean and Palaeoproterozoic ultramaficmafic rocks from the southern and northern parts of Mawson Escarpment may originate from similar mantle sources, which proves that both areas belong to a single (Ruker) Province, as suggested by Phillips et al. (2006). However, these authors and Mikhalsky et al. (2006) also emphasized that the central and northern parts of the Mawson Escarpment are underlain, unlike the southern part of it, by Proterozoic orthogneisses and metasediments. Hence, these areas (Lambert Terrane by Kamenev et al., 1993, Mikhalsky et al., 2006) are most likely of ensimatic, rather than ensialic origin.

Acknowledgements. We thank the referees for their input that, although not always heeded, have led to improvements in the manuscript. J Gamble is thanked for handling and editing the manuscript. This work was made possible in part by grant from Deutsche Forschungsgemeinschaft and grant from Russian Foundation for Basic Research 07-05-01001 to EVM.

\section{References}

Belyatsky, B.V., E.N. Kamenev, A.A. Laiba, and E.V. Mikhalsky (2003), $\mathrm{Sm}-\mathrm{Nd}$ ages of metamorphosed volcanic and plutonic rocks from Mount Ruker, the southern Prince Charles Mountains, East Antarctica, in Programme and Abstracts, $9^{\text {th }}$ ISAES, Schriften der Alfred-WegenerStiftung 2003/2004, 24-25.

Bennett, V.C., A.P Nutman, and M.T. McCulloch (1993), Nd isotopic evidence for transient, highly depleted mantle reservoirs in the early history of the Earth, Earth and Planet. Science Letters, 119, 299-317.

Boger, S.D., C.J.L. Wilson, and C.M. Fanning (2006), An Archaean province in the southern Prince Charles Mountains, East Antarctica: U$\mathrm{Pb}$ zircon evidence for c. $3170 \mathrm{Ma}$ granite plutonism and c. $2780 \mathrm{Ma}$ partial melting and orogenesis, Precambrian Research, 145, 207-228.

Grikurov, G.E., and E.V. Mikhalsky (2002), Tectonic structure and evolution of East Antarctica in the light of knowledge about supercontinents, Russian Journal of Earth Sciences, 4, 247-257.

Harley, S.L., and L.P. Black (1997), A revised Archaean chronology for the Napier Complex, Enderby Land, from SHRIMP ion-microprobe studies, Antarctic Science, 9, 74-91.

Kamenev, E.N., A.V.Andronikov, E.V.Mikhalsky, N.N. Krasnikov, and K. Stüwe (1993), Soviet geological maps of the Prince Charles Mountains, East Antarctic Shield, Australian Journal of Earth Sciences, 40, 501-517.

Mikhalsky, E.V., J.W.Sheraton, A.A. Laiba, R.J. Tingey, D.E. Thost, E.N. Kamenev, and L.V.Fedorov (2001), Geology of the Prince Charles Mountains, Antarctica, AGSO - Geoscience Australia Bulletin 247,209 pp.

Mikhalsky, E.V., B.V. Beliatsky, J.W. Sheraton, and N.W. Roland (2006), Two distinct Precambrian terranes in the southern Prince Charles Mountains, East Antarctica: SHRIMP dating and geochemical constraints, Gondwana Research, 9, 291-309.

Phillips, G., C.J.L. Wilson, I.H. Campbell, and C.M. Allen (2006), U$\mathrm{Th}-\mathrm{Pb}$ detrital zircon geochronology from the southern Prince Charles Mountains, East Antarctica - defining the Archaean to Neoproterozoic Ruker Province, Precambrian Research, 148, 292-306. 